\title{
Labyrinthe
}

$11 \mid 2002$

Numéro 11

\section{Euralille : histoire et mémoire d'un projet urbain complexe}

\section{Florence Wierre}

\section{Q OpenEdition \\ 1 Journals}

\section{Electronic version}

URL: http://journals.openedition.org/labyrinthe/668

DOI: $10.4000 /$ labyrinthe.668

ISSN: 1950-6031

\section{Publisher}

Hermann

\section{Printed version}

Date of publication: 14 January 2002

Number of pages: 127-129

\section{Electronic reference}

Florence Wierre, « Euralille : histoire et mémoire d'un projet urbain complexe », Labyrinthe [Online],

11 | 2002, Online since 15 April 2005, connection on 03 May 2019. URL : http://

journals.openedition.org/labyrinthe/668; DOI : 10.4000/labyrinthe.668

This text was automatically generated on 3 May 2019.

Propriété intellectuelle 


\section{Euralille : histoire et mémoire d'un projet urbain complexe}

Florence Wierre 